\title{
ANALYSIS OF THE RELATIONSHIP BETWEEN FATNESS OF LATE PREGNANT AND LACTATING SOWS AND SELECTED LIPID PARAMETERS OF BLOOD, COLOSTRUM AND MILK*
}

\author{
Anna Rekiel, Justyna Więcek, Karolina Beyga \\ Department of Pig Breeding, Warsaw University of Life Sciences, \\ Ciszewskiego 8, 02-786 Warszawa, Poland \\ Corresponding author: anna_rekiel@sggw.pl
}

\begin{abstract}
This study determined the relationships between backfat thickness in sows on day $104( \pm 2)$ of pregnancy, changes in fatness between high pregnancy and lactation (day 21), the body weight of late pregnant sows, the level of selected lipid parameters in blood serum, and basic components and fatty acid profile of colostrum and milk. Backfat measurements were taken using an ultrasound device at the P1, P2, P3 and P4 sites and loin eye height was measured at the P4M site. In late pregnant sows, fatness measured at $\mathrm{P1}, \mathrm{P2}, \mathrm{P} 3$ and $\mathrm{P} 4$ and the mean of measurements taken at $\mathrm{P2}$ and P4 were correlated with HDL $(+0.491 * *,+0.537 * *,+0.439 *,+0.483 * *$ and $0.529 * *$, respectively). Measurements taken at $\mathrm{P} 4$ and the mean of $\mathrm{P2}$ and $\mathrm{P} 4$ were correlated with cholesterol (CHOL, $+0.367^{*}$ and $+0.372 *$, respectively). Correlations were also found between the level of fatness of pregnant sows $(\mathrm{P} 2, \mathrm{P3}, \mathrm{P} 4,(\mathrm{P} 2+\mathrm{P4}) / 2)$ and the level of HDL at the end of lactation $(+0.534 * *$, $+0.440 *,+0.412 *$ and $+0.487 * *$, respectively). The body weight of late pregnant sows was significantly correlated with the energy and fat levels in colostrum $\left(-0.467^{* *}\right.$ and $-0.429^{*}$, respectively). In addition, it was correlated with the proportion of fatty acids in the profile $\left(\mathrm{C} 18: 2+0.417^{*}\right.$, C18:3 +0.493*). Correlations were observed between P1 backfat thickness and the proportion of colostrum fatty acids $\left(\mathrm{C18}: 1+0.483^{*}, \mathrm{CLA}+0.475^{*}\right)$, and between $\mathrm{P} 2$ backfat thickness and the C20:4 content of milk $(-0.421 *)$. A relationship between backfat thickness measured at farrowing and the levels of selected fatty acids in colostrum was found for P2 and C18:3 (+0.471*), P3 and C18:0 $\left(-0.608^{* *}\right), C 18: 2\left(+0.463^{*}\right)$ and C18:3 $\left(+0.517^{*}\right)$, and P4M and C16:1 $\left(-0.513^{*}\right)$. The greater the difference in $P 1$ backfat thickness between late pregnancy and weaning, the higher the content of fat $\left(+0.549^{* *}\right)$, energy $\left(+0.510^{*}\right)$, C18:0 $\left(+0.493^{*}\right)$ and CLA $\left(+0.488^{*}\right)$, and the lower the content of $\mathrm{C14:0}\left(-0.512^{*}\right)$ and $\mathrm{C} 16: 0\left(-0.457^{*}\right)$ in milk. The strong correlations of fatness in late pregnant sows and of changes in fatness during late pregnancy and weaning with some blood, colostrum and milk parameters suggest that sows should be evaluated for fatness during their productive life.
\end{abstract}

Key words: sows, correlations, fatness, lipid parameters, blood, colostrum, milk

\footnotetext{
* Source of research financing: author's project of the State Committee for Scientific Research, project no. N N311 082639 and statutory activity no. 5052007030040.
} 
The pigs' body fat content has decreased over time as a result of long-term breeding (Rekiel, 2002). Lower lipid reserves in gilts and sows reduce their productive life, which is undesirable from the perspective of production and economics.

Studies concerning the effects of genotype, environment, state of nourishment and fat reserves on the parameters of reproduction and lactation and on sows' biochemical equilibrium suggest that the above-mentioned factors influence fertility and reproductive longevity of females (Jezková and Smrcková, 1991; Rekiel, 2002; Žvorc et al., 2006). These factors are related to the quantity and quality of colostrum and milk produced by the sows, thus affecting the survival levels and the growth rate of piglets during neonatal and rearing periods (Beyga and Rekiel, 2009).

The findings of Walkiewicz et al. (1994) and Revell et al. (1998) indicate that milk composition is rather stable, with the exception of fat. These results are fundamental for analysis of the use of fat additives in sows' nutrition and determination of their effects on the quality of maternal milk and colostrum as well as on rearing performance of the offspring (Migdał et al., 2003; Mazur and Stasiak, 2006). Few studies have determined the effect of the sow's (mother's) body condition and her fat reserves, including subcutaneous fat (backfat thickness), on metabolic processes, indicators of biochemical equilibrium, and quantitative and qualitative properties of mammary secretion (Bakke and Vold, 1975; Walkiewicz et al., 1994; Revell et al., 1998; Rekiel, 2002; Beyga and Rekiel, 2009, 2010).

The aim of the current study was to determine the relationship between fatness in late pregnant and lactating sows and some lipid parameters of serum, colostrum and milk.

\section{Material and methods}

The study involved 32 Polish Large White $\times$ Polish Landrace sows. The number of sows was representative for the herd, with 5-6 animals in successive production cycles, i.e., from the first to the sixth. A Piglog 105 ultrasound device was used to measure their backfat thickness: $3 \mathrm{~cm}$ off the midline (P1 - over the shoulder, P2 behind the last rib, P3 - over the gluteus medius muscle), $8 \mathrm{~cm}$ off the midline (P4 - behind the last rib); and loin eye height at P4 (P4M). The measurements were taken for pregnant sows on day 104 of pregnancy ( \pm 2 days), at farrowing, and on day 21 of lactation. Animals were weighed on day 104 of pregnancy and on day 21 of lactation (first and third dates) (Table 1).

Sows were managed and fed individually. Pregnant sows received feed mixture twice daily and nursing sows three times a day. From day 104 of pregnancy (when sows were moved to the parturition area) until the end of lactation, they were fed a diet in accordance with the Nutrient Requirements for Pigs (1993); $1 \mathrm{~kg}$ of the mixture contained $2270 \mathrm{kcal}, 17 \%$ of protein and 1\% of lysine (AOAC, 1995). During a 3 -week lactation, on average, each sow consumed $103.2 \mathrm{~kg}$ of the mixture. From 5 days of age, piglets were supplemented with a prestarter diet. Sows and piglets were under veterinary supervision and a prophylaxis programme. 
Table 1. Characteristics of the herd of sows

\begin{tabular}{|c|c|c|c|}
\hline Traits & Day 104 of pregnancy & Farrowing day & Weaning day \\
\hline Body weight $(\mathrm{kg})$ & $229.0 \pm 37.44$ & & $197.2 \pm 32.94$ \\
\hline $\begin{array}{l}\text { Backfat thickness over the shoulder, } 3 \\
\mathrm{~cm} \text { off the midline, at P1 (mm) }\end{array}$ & $31.2 \pm 7.84$ & $34.3 \pm 7.09$ & $29.1 \pm 8.85$ \\
\hline $\begin{array}{l}\text { Backfat thickness behind the last rib, } \\
3 \mathrm{~cm} \text { off the midline, at } \mathrm{P} 2(\mathrm{~mm})\end{array}$ & $19.9 \pm 5.94$ & $19.6 \pm 5.69$ & $16.4 \pm 5.78$ \\
\hline $\begin{array}{l}\text { Backfat thickness over the gluteus } \\
\text { medius muscle, } 3 \mathrm{~cm} \text { off the midline, } \\
\text { at } \mathrm{P} 3(\mathrm{~mm})\end{array}$ & $25.5 \pm 7.57$ & $26.1 \pm 7.01$ & $21.1 \pm 6.65$ \\
\hline $\begin{array}{l}\text { Backfat thickness behind the last rib, } \\
8 \mathrm{~cm} \text { off the midline, at } \mathrm{P} 4(\mathrm{~mm})\end{array}$ & $21.9 \pm 6.91$ & $23.0 \pm 7.02$ & $17.4 \pm 7.69$ \\
\hline $\begin{array}{l}\text { Arithmetic mean of backfat thickness } \\
(\mathrm{P} 2+\mathrm{P} 4) / 2(\mathrm{~mm})\end{array}$ & $20.9 \pm 6.18$ & $21.3 \pm 5.94$ & $16.9 \pm 6.55$ \\
\hline Loin eye height at $\mathrm{P} 4 \mathrm{M}(\mathrm{mm})$ & $43.6 \pm 6.03$ & $43.1 \pm 4.13$ & $40.9 \pm 4.10$ \\
\hline
\end{tabular}

Blood of sows was collected twice for biochemical analysis before morning feeding (on day 104 of pregnancy and on day 21 of lactation). Blood was drawn from the vena cava cranialis into clean tubes, allowed to clot and centrifuged (10 $\mathrm{min}$, $3500 \mathrm{r} . / \mathrm{min})$. The following biochemical indicators were determined in blood serum: total cholesterol (CHOL), triacylglycerides (TRIG) and high-, low-, and very low-density lipoproteins (HDL, LDL, VLDL). Determinations were made with a VITROS DT 60 II System using diagnostic kits from ICN Instruments Poland Ltd (Table 2).

Table 2. The lipid parameters of serum $(\mathrm{mg} / \mathrm{dl})$

\begin{tabular}{c|c|c}
\hline Traits & Day 104 of pregnancy & Weaning day \\
\hline TRIG & $0.66 \pm 0.300$ & $0.37 \pm 0.102$ \\
CHOL & $2.00 \pm 0.355$ & $1.81 \pm 0.346$ \\
HDL & $0.84 \pm 0.174$ & $0.80 \pm 0.164$ \\
LDL & $0.87 \pm 0.265$ & $0.83 \pm 0.274$ \\
VLDL & $0.26 \pm 0.121$ & $0.15 \pm 0.041$ \\
\hline
\end{tabular}

After injection of oxytocin ( $1 \mathrm{ml} / 100 \mathrm{~kg} \mathrm{b.w.),} \mathrm{samples} \mathrm{of} \mathrm{colostrum} \mathrm{and} \mathrm{milk}$ were collected from sows $(50 \mathrm{ml})$ during parturition and at weaning, and preserved (Mlekostat CC). They were analysed for the content of fat, protein, lactose and solids with the infrared spectrophotometry method using a Milkoscan FT 120 analyser (Foss Electric). Colostrum and milk fat were extracted using the method of RöseGottlieb (AOAC, 1995). Energy (kJ) was calculated after Ruszczyc (1985). Determinations were established with respect to the content of fat $(\%)$ and proportion of fatty acids in the profile (C14:0, C16:0, C16:1, C18:0, C18:1, C18:2, CLA (C18:2 $\left.\left.{ }_{\text {cis } 9 \text { trans } 11}\right), \mathrm{C} 18: 3, \mathrm{C} 20: 4\right)$. Supelco standards and Mix C4-C24 were used. The analyses were performed in duplicate. The content of individual isomers was calculated as a mean result of two measurements (Table 3 ). 
Table 3. Energy, basic composition and proportion of selected fatty acids in the lipid fraction of colostrum and milk of sows

\begin{tabular}{l|c|c}
\hline \multicolumn{1}{c|}{ Traits } & Farrowing day & Weaning day \\
\hline Energy (kJ) & $1577.83 \pm 244.72$ & $1085.40 \pm 95.64$ \\
Solids (\%) & $26.13 \pm 3.32$ & $18.13 \pm 1.00$ \\
Crude protein (\%) & $15.98 \pm 2.55$ & $3.94 \pm 0.41$ \\
Lactose (\%) & $3.63 \pm 0.44$ & $6.10 \pm 0.35$ \\
Fat (\%) & $5.42 \pm 1.96$ & $6.36 \pm 1.13$ \\
C14:0 & $2.04 \pm 0.37$ & $3.54 \pm 0.54$ \\
C16:0 & $25.41 \pm 1.91$ & $34.09 \pm 3.85$ \\
C16:1 & $3.12 \pm 0.39$ & $9.65 \pm 2.48$ \\
C18:0 & $5.56 \pm 0.69$ & $4.73 \pm 0.81$ \\
C18:1 & $32.01 \pm 1.91$ & $30.30 \pm 5.08$ \\
C18:2 & $15.98 \pm 1.45$ & $8.46 \pm 0.69$ \\
CLA - C18:2 $2_{\text {cis9 trans11 }}$ & $0.35 \pm 0.06$ & $0.39 \pm 0.15$ \\
C18:3 & $1.38 \pm 0.15$ & $0.72 \pm 0.09$ \\
C20:4 & $1.09 \pm 0.11$ & $0.46 \pm 0.07$ \\
\hline
\end{tabular}

Results are presented as means \pm standard deviations. The Pearson correlations were calculated in SPSS software (SPSS, 2006). Only significant $(\mathrm{P} \leq 0.05, \mathrm{P} \leq 0.01)$ correlations were presented.

\section{Results}

Table 1 presents selected characteristics of sows included in the analysis. Table 2 shows major lipid biochemical indicators of the serum. Table 3 gives the energy content, basic composition and selected fatty acid levels of the lipid fraction of colostrum and milk.

Significant and highly significant positive correlations were found in the serum of late pregnant sows between P1, P2, P3 and P4 backfat thickness and the mean of P2 and P4 measurements and HDL, and between P4 and (P2 + P4)/2 and CHOL. Correlations were also found between P2, P3, P4, (P2 + P4)/2 fatness and serum HDL levels for sows at 21 days of lactation (Table 4). The correlation coefficients were lower for late lactation than for pregnancy. The body weight of late pregnant sows was negatively correlated with the energy $(\mathrm{P} \leq 0.01)$ and fat $(\mathrm{P} \leq 0.05)$, and positively correlated with $\mathrm{C} 18: 2$ and $\mathrm{C} 18: 3(\mathrm{P} \leq 0.05)$ content in the colostrum (Table 5). Significant positive relationships $(\mathrm{P} \leq 0.05)$ were observed between $\mathrm{P} 1$ backfat thickness and the content of fatty acids in colostrum (C18:1, CLA). Negative relationships were observed between P2 backfat thickness and the proportion of C20:4 in milk (Table 5). A statistically significant relationship between backfat thickness meas- 
ured at farrowing and the proportion of selected fatty acids in colostrum (statistically significant at $\mathrm{P} \leq 0.05$ or $\mathrm{P} \leq 0.01$ ) was observed between $\mathrm{P} 2$ and $\mathrm{C} 18: 3$, and between P3 and C18:0, C18:2 and C18:3 (Table 6). Moreover, correlations were identified between $\mathrm{P} 4 \mathrm{M}$ loin eye height and the proportion of $\mathrm{C} 16: 1$. As the difference in $\mathrm{P} 1$ backfat thickness between late pregnancy and weaning increased, it was observed that the milk of sows contained more fat $(\mathrm{P} \leq 0.01)$, energy, $\mathrm{C} 18: 0$ and CLA $(\mathrm{P} \leq 0.05)$, and less $\mathrm{C} 14: 0$ and $\mathrm{C} 16: 0(\mathrm{P} \leq 0.05)$ (Table 7). The correlations of the remaining relationships analysed were low and statistically non-significant, and were excluded from results.

Table 4. Correlations between backfat thickness and loin eye height of sows in late pregnancy and selected lipid parameters of blood of pregnant and nursing sows

\begin{tabular}{l|l|l|l|c}
\hline \multirow{2}{*}{$\begin{array}{c}\text { Measurements during late } \\
\text { pregnancy of sows }\end{array}$} & \multicolumn{3}{|c}{ Late pregnancy } & \multicolumn{2}{c}{ Lactation (day 21) } \\
\cline { 2 - 5 } & CHOL & HDL & CHOL & HDL \\
\hline P1 & 0.228 & $0.491^{* *}$ & 0.052 & 0.276 \\
P2 & 0.345 & $0.537^{* *}$ & 0.319 & $0.534^{* *}$ \\
P3 & 0.185 & $0.439^{*}$ & 0.137 & $0.440^{*}$ \\
P4 & $0.367^{*}$ & $0.483^{* *}$ & 0.341 & $0.412^{*}$ \\
(P2 + P4)/2 & $0.372^{*}$ & $0.529 * *$ & 0.344 & $0.487 * *$ \\
P4M & 0.043 & -0.035 & 0.257 & 0.075 \\
\hline
\end{tabular}

$* * \mathrm{P} \leq 0.01, * \mathrm{P} \leq 0.05$.

$\mathrm{P} 1$ - backfat thickness over the shoulder, $3 \mathrm{~cm}$ off the midline.

P2 - backfat thickness behind the last rib, $3 \mathrm{~cm}$ off the midline.

P3 - backfat thickness over the gluteus medius muscle, $3 \mathrm{~cm}$ off the midline.

P4 - backfat thickness behind the last rib, $8 \mathrm{~cm}$ off the midline.

$\mathrm{P} 4 \mathrm{M}$ - loin eye height at $\mathrm{P} 4$.

CHOL - cholesterol.

HDL - high density lipoproteins.

Table 5. Correlations between body weight and backfat thickness of sows during late pregnancy and selected lipid parameters of colostrum and milk

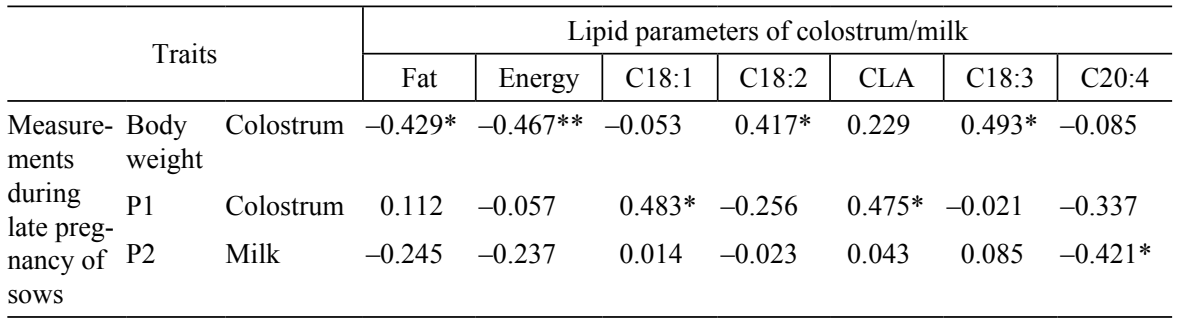

** $\mathrm{P} \leq 0.01, * \mathrm{P} \leq 0.05$.

$\mathrm{P} 1$ - backfat thickness over the shoulder, $3 \mathrm{~cm}$ off the midline.

$\mathrm{P} 2$ - backfat thickness behind the last rib, $3 \mathrm{~cm}$ off the midline. 
Table 6. Correlations between backfat thickness and loin eye height of sows at farrowing and the proportion of selected fatty acids in colostrum

\begin{tabular}{ll|c|c|c|c}
\hline \multirow{2}{*}{ Traits } & \multicolumn{4}{c}{ Colostrum fatty acids } \\
\cline { 3 - 6 } \multicolumn{2}{c|}{} & C16:1 & C18:0 & C18:2 & C18:3 \\
\hline Measurements for sows & P2 & 0.088 & -0.297 & 0.313 & $0.471^{*}$ \\
at farrowing & P3 & 0.199 & $-0.608^{* *}$ & $0.463^{*}$ & $0.517^{*}$ \\
& P4M & $-0.513^{*}$ & 0.244 & 0.197 & 0.339 \\
\hline
\end{tabular}

** $\mathrm{P} \leq 0.01, * \mathrm{P} \leq 0.05$.

P2 - backfat thickness behind the last rib, $3 \mathrm{~cm}$ off the midline.

P3 - backfat thickness over the gluteus medius muscle, $3 \mathrm{~cm}$ off the midline.

$\mathrm{P} 4 \mathrm{M}$ - loin eye height behind the last rib, $8 \mathrm{~cm}$ off the midline.

Table 7. Correlations between the difference in P1 fatness of sows (late pregnancy - weaning) and selected lipid parameters of milk at 21 days of lactation

\begin{tabular}{l|c|c|c|c|c|c}
\hline \multirow{2}{*}{ Traits } & \multicolumn{6}{c}{ Lipid parameters of milk at 21 days of lactation } \\
\cline { 2 - 7 } & Fat & Energy & C14:0 & C16:0 & C18:0 & CLA \\
\hline $\begin{array}{l}\text { Difference for sows in P1 } \\
\text { late pregnancy - weaning) }\end{array}$ & $0.549^{* *}$ & $0.510^{*}$ & $-0.512^{*}$ & $-0.457^{*}$ & $0.493^{*}$ & $0.488^{*}$ \\
\hline
\end{tabular}

** $\mathrm{P} \leq 0.01, * \mathrm{P} \leq 0.05$

$\mathrm{P} 1$ - backfat thickness over the shoulder, $3 \mathrm{~cm}$ off the midline.

\section{Discussion}

In the present study, the correlations identified between serum CHOL and HDL and fatness of pregnant and nursing sows indicate the substantial role of blood in the lipid metabolism (Jezková and Smrcková, 1991; Kandeh et al., 1993; Žvorc et al., 2006).

The chemical composition of colostrum and milk, including solids, fat and protein, undergoes changes during lactation (Migdał et al., 2003; Beyga and Rekiel, 2009). The results of the present study are comparable with those reported by Migda1 et al. (2000). According to Walkiewicz et al. (1994) and Revell et al. (1998), changes in the protein to energy ratio in milk in the early stage of lactation may depend on the sow's "body composition". This ratio shows a greater potential for using amino acids from the slim mother's body (more muscular) for milk protein synthesis. Fat reserves stored in the body prior to parturition can be a source of compounds for the synthesis of components that increase the energy content of food in the initial phase of its production and secretion (Beyga and Rekiel, 2009). In the next stages of lactation, the external components (feed) become more important, as they become precursors of the production milk ingredients. As a result, the colostrum and milk energy content can be dietarily influenced by the increasing fat content in the feed (Migdał et al., 2003). The effects might be expected if fat enhanced feed is offered at least 10-15 days before the expected parturition and during lactation. Moreover, it can be expected that the fat reserves of late pregnant sows, which are later used by 
the sows in the lactation period, may have an impact on the level of lipid indicators in the circulating blood and in the colostrum and milk produced by sows.

The results of analyses performed by Beyga and Rekiel (2009) indicate that colostrum energy and fat content were lower in late pregnant sows with thinner backfat than in females with thicker backfat (Beyga and Rekiel, 2009). Revell et al. (1998) confirmed the relationship between fatness of sows and milk fat content in early lactation. Fat content was higher in the milk of sows with thicker backfat compared to females with thinner backfat.

The analyses of milk led to a conclusion that milk content depends on the breed, feeding, lactation number and lactation phase (Migdał et al., 2000). According to Revell et al. (1998), the milk content cannot be changed due to external additives to feed or internal body reserves. Milk fat is the exception. The cited authors observed the impact of the fatness of sows on lactose content in the milk produced. These results were not confirmed by analyses performed by Beyga and Rekiel (2009). However, Walkiewicz et al. (1994), Revell et al. (1998) and Beyga and Rekiel (2009) reported correlations between the fatness of sows and lipid content in milk.

Body reserves and feed components provide mothers with substrates for production of food for their offspring (Walkiewicz et al., 1994; Revell et al., 1998; Migdał et al., 2003; Beyga and Rekiel, 2009). The nutritional status of a pregnant sow, its condition, feeding level during lactation and lactation itself determine the synthesis of colostrum and milk components (Rekiel, 2003). Excessively fat sows, however, due to lower number of follicular secretory cells, reduce the production of colostrum and milk by approximately 15\% (Revell et al., 1998; Young et al., 2004). The production and energy value of the diet at the beginning of lactation is greater when feeding gilts during the rearing period enables the female's body to store optimal reserves. This is reflected in the sow's body weight and backfat thickness (Cozler et al., 1998).

Feeding of sows with diets containing low and high levels of fat during lactation affects the metabolism of fat. The higher the fat supply, the greater the metabolism. However, it does not impact the level of fat in milk (Theil et al., 2004). Different lipid levels in feed have an effect on the level of its consumption. High supply of fat results in lower feed consumption at 3 and 4 weeks of lactation, which is undesirable. This shows the need of controlling the fat levels in sows. Fat is the natural source of substrates for production of various lipids of colostrum and milk.

Walkiewicz et al. (1994) demonstrated that the level of some unsaturated fatty acids in milk fat depends on backfat thickness at mating. The milk of gilts with thicker backfat contained more $\mathrm{C} 16: 1$ and $\mathrm{C} 18: 2$, and that of gilts with thinner backfat had a higher C18:1 content. Beyga and Rekiel (2009) showed differences in fatty acid profile between milk and colostrum. The content of C14:0, C16:0 and C16:1 increased significantly $(\mathrm{P} \leq 0.01)$ and that of CLA only numerically in milk, while the level of other fatty acids decreased $(\mathrm{P} \leq 0.01)$ more significantly than that in colostrum. The findings of Beyga and Rekiel (2009) confirm the increase in PUFA level during lactation, which was observed by Migdał et al. (2000).

The literature on the relationship between fatness and levels of feeding and lipid indicators in serum, colostrum and milk is rather limited. The sows' lipid metabo- 
lism was investigated by Kandeh et al. (1993), who selected sows with high and low levels of cholesterol in serum over three generations. They observed that such selection has an impact on milk fat and cholesterol levels. The correlations between cholesterol levels in serum and milk and CHOL levels in serum and milk fat were $r=0.782$ and $r=0.360$, respectively. The hypothesis that the cholesterol content in milk is related to its level in serum was confirmed. This shows the possibility of line selection with respect to high levels of fat and cholesterol in milk.

The greater the changes in fatness of sows between late pregnancy and late lactation, the higher the fat content and energy contents of milk. This relationship determines better quality of milk for suckling piglets and, therefore, enables piglets to make better use of their genetically conditioned potential for growth and development. The correlations found between fatness of late pregnant sows and selected parameters of blood (HDL), colostrum and milk (content of fat, energy and fatty acids) and changes in fat reserves between late pregnancy and weaning period, and the above mentioned lipid parameters of blood, colostrum and milk, indicate the need to evaluate the fatness of sows during their productive life. The aim of the future evaluation of the fatness of sows is to obtain information about the body condition of females and to determine the optimum duration of lactation. Moreover, it may also indicate the possible need for introducing dietary manipulations in sows.

\section{References}

A O A C (1995). Association of Official Analytical Chemists. Official Methods of Analysis. 16th Edition, Arlington VA, USA

B a k k e H., V o ld E. (1975). Milk composition in lines of pigs selected for rate of gain and thickness of backfat. Acta Vet. Scand., Sec. A, Anim. Sci., 25: 325-329.

B e y g a K., R e ki e l A. (2009). Effect of the backfat thickness of sows in late pregnancy on the composition of colostrum and milk. Arch. Anim. Breed., 52: 593-602.

B e y g a K., R e k i e 1 A. (2010). The effect of the body condition of late pregnant sows on fat reserves at farrowing and weaning and on litter performance. Arch. Anim. Breed., 53: 50-64.

Cozler Y., David C., B e a mal V., Hulin J.C., Ne il M., D o u rmad J.Y. (1998). Effect of the feeding level during rearing on performance of large white gilts. Part 1: Growth, reproductive performance and feed intake during the first lactation. Reprod. Nutr. Develop., 38: 363-375.

Jezková D., S m rcková M. (1991). Changes in lipid level in the blood of pregnant sows. Vet. Med., 36: 599-606.

K a n d e h M., P ark Y.W., P on d W.G., Young L.D. (1993). Milk cholesterol concentration in sows selected for three generations for high or low serum cholesterol. J. Anim. Sci., 71: 1100-1103.

M a z u r A., S t a s i k A. (2006). Influence of raw fat impact in diet on the chemical composition and a profile of fatty acids of sows milk PL and Pulawska breeds (in Polish). Ann. UMCS, Sectio EE XXIV, 21: 147-154.

Migdał W., Pieszka M., B arowicz T., P ietras M. (2003). Chemical composition of colostrum and milk of sows receiving CLA in feed. (In Polish). Med. Wet., 59: 327-330.

Migdał W., Živkovi č B., F a bian M. (2000). Chemical composition of colostrum and milk in lactation of sows. Biotechnol. Anim. Husb., 17: 31-38.

Nutrient Requirements for Pigs (1993). Nutritional value of feeds. (In Polish). Omnitech Press, Warszawa, pp. $1-87$.

R e ki el A. (2002). Effect of different drying off methods on the level of fat reserves and production results in sows. (In Polish). Pr. hab., 246. Wyd. SGGW, pp. 1-99. 
R e k i e l A. (2003). The chosen problems of physiology and productive of lactation of sow. (In Polish). Acta Scien. Polon., 2: 101-112.

Revell D.K., William s I.H., Mulla n B.P., R a n ford J.L., S mits R.J. (1998). Body composition at farrowing and nutrition during lactation affect the performance of primiparous sows: II. Milk composition, milk yield, and pig growth. J. Anim. Sci., 76: 1738-1743.

SPSS 2006. User's Guide 12.0. SPSS Inc.

The il P., J or g e n s e n H., J a k obs e n K. (2004). Energy and protein metabolism in lactating sows fed two levels of dietary fat. Liv. Prod. Sci., 89: 265-276.

W a lki e wi c z A., W i elbo E., K a myk P., S t a si a k A. (1994). Effect of somatic development of gilts on the initial reproduction lactation ability and chemical composition of milk. (In Polish). Ann. UMCS, Sectio EE XII, 12: 81-87.

Young M.G., Tokach M.D., Aherne F.X., Main R.G., Dritz S.S., Goodband R.D., $\mathrm{N}$ e l s s e $\mathrm{n}$ J.L. (2004). Comparison of three methods of feeding sows in gestation and the subsequent effects on lactation performance. J. Anim. Sci., 82: 3058-3070.

Žvorc Z., Mrljak V., Sušić V., Pompe Gotal J. (2006). Haematological and biochemical parameters during pregnancy and lactation in sows. Vet. Arhiv. 76: 245-253.

Accepted for printing 18 VII 2011

\title{
ANNA REKIEL, JUSTYNA WIĘCEK, KAROLINA BEYGA
}

\author{
Analiza związku otluszczenia loch w ciąży wysokiej i w laktacji z wybranymi wskaźnikami \\ lipidowymi krwi, siary i mleka
}

\section{STRESZCZENIE}

Określono związek grubości słoniny u loch $(\mathrm{n}=32)$ w $104 \pm 2$ dniu ciąży, zmian otłuszczenia w okresie: ciąża wysoka - laktacja (21. dzień) oraz masy ciała wysokoprośnych loch z poziomem wybranych wskaźników lipidowych w surowicy krwi oraz składnikami podstawowymi i profilem kwasów thuszczowych siary i mleka. Pomiary słoniny wykonano aparatem ultradźwiękowym w punktach P1, P2, P3, P4, a wysokości „oka” polędwicy w punkcie P4M. U loch wysokoprośnych stwierdzono zależności pomiędzy otłuszczeniem $\mathrm{w}$ punktach $\mathrm{P} 1, \mathrm{P} 2, \mathrm{P} 3, \mathrm{P} 4$ oraz średnią z pomiarów w pkt P2 i P4 - (P2 + P4)/2) a HDL; korelacje wyniosły odpowiednio: $+0,491^{* *},+0,537^{* *},+0,439^{*},+0,483^{* *}$, $0,529 * *$, a także $\mathrm{P} 4 \mathrm{i}(\mathrm{P} 2+\mathrm{P} 4) / 2$ a CHOL: $+0,367 * \mathrm{i}+0,372 *$. Wystąpiły teżkorelacje między otłuszczeniem prośnych loch $(\mathrm{P} 2, \mathrm{P} 3, \mathrm{P} 4,(\mathrm{P} 2+\mathrm{P} 4) / 2))$ a poziomem HDL po zakończonej laktacji: $+0,534 * *,+0,440 *$, $+0,412^{*},+0,487^{* *}$. Istotne korelacje wykazano między masą ciała loch w ciąży wysokiej a ilością energii i thuszczu w siarze, odpowiednio: $-0,467 * *,-0,429 *$ oraz procentowym udziałem kwasów thuszczowych w profilu: $\mathrm{C} 18: 2+0,417^{*}, \mathrm{C} 18: 3+0,493 *$. Korelacje wystąpiły między grubością słoniny w punkcie P1 a udziałem kwasów thuszczowych siary: C18:1 $+0,483^{*}$, CLA $+0,475^{*}$ oraz między grubością słoniny w pkt P2 a udziałem w mleku kwasu C20:4 $(-0,421 *)$. Związek między grubością słoniny mierzoną przy oproszeniu loch a udziałem niektórych kwasów thuszczowych siary wykazano dla: P2 i C18:3 $\left(+0,471^{*}\right)$, P3 i C18:0 (-0,608**), C18:2 $\left(+0,463^{*}\right), \mathrm{C} 18: 3\left(+0,517^{*}\right)$ oraz P4M i C16:1 $\left(-0,513^{*}\right)$. Stwierdzono, że im większa jest różnica w grubości słoniny w punkcie P1 między ciążą wysoką a odsadzeniem, tym mleko loch zawiera więcej thuszczu $(+0,549 * *)$, energii $\left(+0,510^{*}\right)$, kwasu C18:0 $(+0,493 *)$ i CLA $\left(+0,488^{*}\right)$, a mniej C14:0 $\left(-0,512^{*}\right)$ i C16:0 $\left(-0,457^{*}\right)$. Korelacje między otłuszczeniem loch w ciąży wysokiej i zmianą otłuszczenia (ciąża wysoka - odsadzenie) a niektórymi wskaźnikami krwi, siary i mleka wskazują na potrzebę oceny otłuszczenia samic w okresie ich użytkowania. 